\title{
molecules
}

ISSN 1420-3049

www.mdpi.com/journal/molecules

Article

\section{Limonoids from the Fruits of Khaya ivorensis}

\author{
Kai-Long Ji ${ }^{1,2}$, Shang-Gao Liao ${ }^{3}$, Xiao-Ling Zheng ${ }^{1,2}$, Zhi Na ${ }^{1}$, Hua-Bin Hu ${ }^{1}$, Ping Zhang ${ }^{1, *}$ \\ and You-Kai Xu ${ }^{1, *}$
}

1 CAS Key Laboratory of Tropical Plant Resource and Sustainable Use, Xishuangbanna Tropical Botanical Garden, Chinese Academy of Sciences, Menglun, Mengla, Yunnan 666303, China

2 University of Chinese Academy of Sciences, Beijing 100049, China

3 Engineering Research Center for the Development and Application of Ethnic Medicines and TCM, School of Pharmacy, Guiyang Medical College, 9 Beijing Road, Guiyang, Guizhou 550004, China

* Authors to whom correspondence should be addressed; E-Mails: zhangping@xtbg.org.cn (P.Z.); xyk@xtbg.ac.cn (Y.-K.X.); Tel.: +86-691-871-3169 (Y.-K.X.); Fax: +86-691-871-3061 (Y.-K.X.).

Received: 22 January 2014; in revised form: 27 February 2014 / Accepted: 28 February 2014 / Published: 7 March 2014

\begin{abstract}
Two new limonoids, namely 14,15-didehydroruageanin A (1) and 3-O-methylbutyrylseneganolide A (2), were isolated from the fruits of Khaya ivorensis along with six known limonoids: seneganolide A (3), 1,3-dideacetylkhivorin (4), 7-deacetylkhivorin (5), 3-deacetylkhivorin (6), 1-deacetylkhivorin (7), and 3-deacetyl-7-oxokhivorin (8). All the compounds were evaluated for their cytotoxicity against five tumor cell lines.
\end{abstract}

Keywords: Khaya ivorensis; limonoids; 14,15-didehydroruageanin A; 3-O-methylbutyrylseneganolide A; cytotoxicity

\section{Introduction}

Meliaceous limonoids, the major metabolites of the Meliaceae family, have attracted great interest in the natural products field due to their structural diversity and broad range of bioactivities [1,2]. Khaya A. Juss. (Meliaceae) is a genus of eight species mainly distributed in Africa and Madagascar [3]. Khaya ivorensis A. Chev. is a popular traditional African medicinal plant in this genus that is also cultivated in southern China [4-6]. Its ethanol stem bark extract has shown tissue toxicity, antimalarial and antiinflammatory activities [5]. Previous chemical investigation of $K$. ivorensis indicated that this plant was a good source of limonoids [6-11]. As a continuation of our studies of this medicinal plant in 
search of biologically significant secondary metabolites, the fruits of $K$. ivorensis were investigated. As a result, the EtOAc-soluble fraction of the ethanolic extract has produced after extensive column chromatography two new limonoids, 14,15-didehydroruageanin A (1), 3-O-methylbutyrylseneganolide A (2), and six known limonoids 3-8, of which compounds 3, 4, 7, and $\mathbf{8}$ were isolated in this plant for the first time (Figure 1). Their structures were established by NMR spectroscopic method and by comparison with literature data. The cytotoxic activities of all isolated compounds were also tested. Herein, the extraction, isolation, structure elucidation, and cytotoxic evaluation of these compounds are described.

Figure 1. The chemical structures of compounds 1-8.
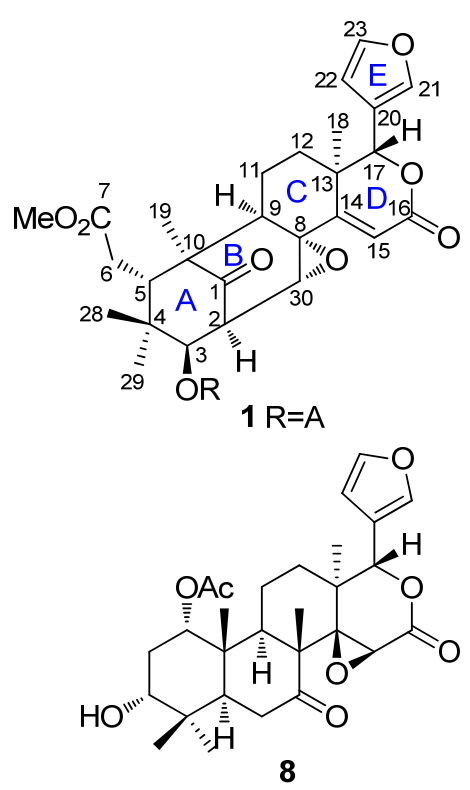
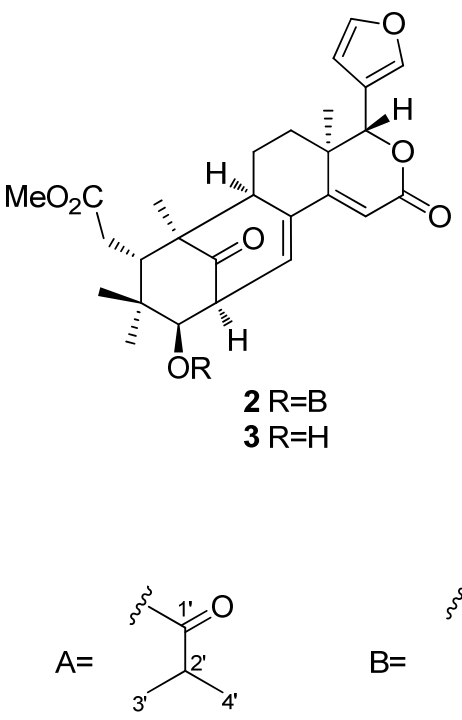

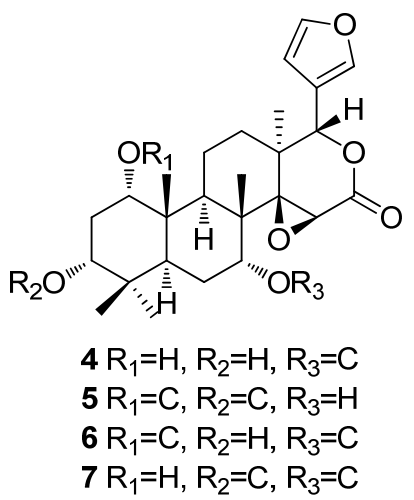

$7 \mathrm{R}_{1}=\mathrm{H}, \mathrm{R}_{2}=\mathrm{C}, \mathrm{R}_{3}=\mathrm{C}$<smiles>CC(=O)C(C)CC(C)C</smiles><smiles>C=CC(C)=O</smiles>

\section{Results and Discussion}

Compound 1, was obtained as a white amorphous powder. Its HREIMS revealed a molecular ion peak at $\mathrm{m} / z 554.2501$ (calcd. 554.2516), consistent with a molecular formula of $\mathrm{C}_{31} \mathrm{H}_{38} \mathrm{O}_{9}$ possessing 13 degrees of unsaturation. The ${ }^{1} \mathrm{H}$ - and ${ }^{13} \mathrm{C}$-NMR (with DEPT) spectra (Table 1) showed, in addition to resonances for an isobutyryl $\left[\delta_{\mathrm{H}} 1.23(3 \mathrm{H}, \mathrm{d}, J=7.1 \mathrm{~Hz}), 1.26(3 \mathrm{H}, \mathrm{d}, J=7.1 \mathrm{~Hz}), 2.81(1 \mathrm{H}, \mathrm{m}) ; \delta_{\mathrm{C}}\right.$ $19.2 \mathrm{CH}_{3}, 19.6 \mathrm{CH}_{3}, 34.9 \mathrm{CH}, 176.0 \mathrm{C}$ ] [12] and a methoxycarbonyl group $\left[\delta_{\mathrm{H}} 3.65(3 \mathrm{H}, \mathrm{s}) ; \delta_{\mathrm{C}} 52.31\right.$ $\left.\mathrm{OCH}_{3}, 174.3 \mathrm{C}\right]$, signals for a ketone $\left(\delta_{\mathrm{C}} 214.8 \mathrm{C}\right)$, four tertiary methyls $\left(\delta_{\mathrm{H}} 0.79 \mathrm{~s}, 0.90 \mathrm{~s}, 1.13 \mathrm{~s}\right.$, $\left.1.22 \mathrm{~s} ; \delta_{\mathrm{C}} 16.1 \mathrm{CH}_{3}, 21.60 \mathrm{CH}_{3}, 21.7 \mathrm{CH}_{3}, 22.9 \mathrm{CH}_{3}\right)$, a furan ring $\left[\delta_{\mathrm{H}} 6.70(1 \mathrm{H}\right.$, br s), $7.70(1 \mathrm{H}$, br s$)$, $7.88\left(1 \mathrm{H}\right.$, br s); $\delta_{\mathrm{C}} 111.4 \mathrm{CH}, 121.1 \mathrm{C}, 143.1 \mathrm{CH}, 144.2 \mathrm{CH}$ ], and an $\alpha, \beta$-unsaturated $\delta$-lactone $\left[\delta_{\mathrm{H}} 6.66\right.$ $\left.(1 \mathrm{H}, \mathrm{s}) ; \delta_{\mathrm{C}} 119.5 \mathrm{CH}, 162.0 \mathrm{C}, 164.6 \mathrm{C}\right]$. An epoxy group was also identified by the NMR data $\left[\delta_{\mathrm{H}}\right.$ $\left.4.51(1 \mathrm{H}, \mathrm{d}, J=2.0) ; \delta_{\mathrm{C}} 61.5 \mathrm{C}, 62.7 \mathrm{CH}\right]$. The above signals accounted for seven out of the 13 degrees of unsaturation and suggested the compound to thus be hexacyclic. These observations indicated that compound 1 was possibly a mexicanolide-type limonoid [12]. 2D-NMR correlation analysis (Figure 2) further confirmed this conclusion and allowed establishment of the full structure for 1. In particular, HMBC correlation from $\mathrm{H}_{2}-6$ to the carboxyl at $\delta_{\mathrm{C}} 174.3$ located the methoxycarbonyl group at C-6, while that from H-3 to the isobutyryl carbonyl placed the isobutyryloxy group at C-3. The epoxy group 
was further revealed to be an 8,30-epoxy by ${ }^{1} \mathrm{H}-{ }^{1} \mathrm{H}$ COSY correlations between $\mathrm{H}-30 / \mathrm{H}-2 / \mathrm{H}-3$ and HMBC correlations H-30/C-8, H-9/C-8, and H-15/C-8 (Figure 2).

Table 1. ${ }^{1} \mathrm{H}$ - and ${ }^{13} \mathrm{C}-\mathrm{NMR}$ of $\mathbf{1}$ and 2 .

\begin{tabular}{|c|c|c|c|c|}
\hline & \multicolumn{2}{|r|}{1} & \multicolumn{2}{|r|}{2} \\
\hline & $\delta_{\mathrm{C}}$, type $^{\mathrm{a}}$ & $\delta_{\mathrm{H}}(J \text { in } \mathrm{Hz})^{b}$ & $\delta_{\mathrm{C}}$, type $^{\mathrm{a}}$ & $\delta_{\mathrm{H}}(J \text { in } \mathrm{Hz})^{b}$ \\
\hline 1 & $214.8, \mathrm{~s}$ & & $214.8, \mathrm{~s}$ & \\
\hline 2 & $49.7, \mathrm{~d}$ & $3.92 \mathrm{dd}(9.3,2.0)$ & $49.9, \mathrm{~d}$ & $3.94 \operatorname{ddd}(9.0,6.1,1.3)$ \\
\hline 3 & $77.6, d$ & $5.39 \mathrm{~d}(9.3)$ & $79.1, \mathrm{~d}$ & $5.14 \mathrm{~d}(9.2)$ \\
\hline 4 & $40.3, \mathrm{~s}$ & & $39.3, \mathrm{~s}$ & \\
\hline 5 & $42.6, \mathrm{~d}$ & $3.67 \mathrm{~d}(2.0)$ & $41.2, \mathrm{~d}$ & $3.57 \mathrm{dd}(7.2,4.7)$ \\
\hline 6 & $33.6, \mathrm{t}$ & $2.44 \mathrm{~m}$ & $33.5, \mathrm{t}$ & $2.55 \mathrm{~m}$ \\
\hline 7 & 174.3, s & & $174.5, \mathrm{~s}$ & \\
\hline 8 & $61.5, \mathrm{~s}$ & & 136.9, s & \\
\hline 9 & $56.3, \mathrm{~d}$ & $2.11 \mathrm{br} \mathrm{s}$ & $54.1, \mathrm{~d}$ & $2.46 \mathrm{~m}$ \\
\hline 10 & $49.0, \mathrm{~s}$ & & $52.5, \mathrm{~s}$ & \\
\hline 11 & $21.59, \mathrm{t}$ & $\alpha 1.22 \mathrm{~m}, \beta 1.65 \mathrm{~m}$ & $22.1, \mathrm{t}$ & $\alpha 1.81 \mathrm{~m}, \beta 1.66 \mathrm{~m}$ \\
\hline 12 & $33.2, \mathrm{t}$ & $\alpha 1.26 \mathrm{~m}, \beta 2.11 \mathrm{~m}$ & $32.9, \mathrm{t}$ & $\alpha 1.19 \mathrm{~m}, \beta 1.95 \mathrm{~m}$ \\
\hline 13 & $39.7, \mathrm{~s}$ & & $38.0, \mathrm{~s}$ & \\
\hline 14 & $162.0, \mathrm{~s}$ & & 161.1, s & \\
\hline 15 & $119.5, \mathrm{~d}$ & $6.66 \mathrm{~s}$ & 113.3, d & $6.57 \mathrm{~s}$ \\
\hline 16 & $164.6, \mathrm{~s}$ & & $165.3, \mathrm{~s}$ & \\
\hline 17 & $80.0, \mathrm{~d}$ & $5.57 \mathrm{~s}$ & $80.1, \mathrm{~d}$ & $5.20 \mathrm{~s}$ \\
\hline 18 & $21.7, \mathrm{q}$ & $1.22 \mathrm{~s}$ & $22.2, \mathrm{q}$ & $1.08 \mathrm{~s}$ \\
\hline 19 & $16.1, \mathrm{q}$ & $1.13 \mathrm{~s}$ & $16.1, \mathrm{q}$ & $1.30 \mathrm{~s}$ \\
\hline 20 & 121.1, s & & 121.6, s & \\
\hline 21 & 143.1, d & 7.88 br s & $142.6, \mathrm{~d}$ & $7.81 \mathrm{~s}$ \\
\hline 22 & $111.4, \mathrm{~d}$ & $6.70 \mathrm{br} \mathrm{s}$ & $111.3, \mathrm{~d}$ & $6.66 \mathrm{~d}(1.0)$ \\
\hline 23 & 144.2, d & 7.70 br s & 144.1, d & $7.67 \mathrm{t}(1.6)$ \\
\hline 28 & $22.9, \mathrm{q}$ & $0.90 \mathrm{~s}$ & $23.0, \mathrm{q}$ & $0.93 \mathrm{~s}$ \\
\hline 29 & $21.60, \mathrm{q}$ & $0.79 \mathrm{~s}$ & $21.4, \mathrm{q}$ & $0.84 \mathrm{~s}$ \\
\hline 30 & $62.7, \mathrm{~d}$ & $4.51 \mathrm{~d}(2.0)$ & $129.8, \mathrm{~d}$ & $6.55, \mathrm{dd}(6.0,2.9)$ \\
\hline 7-OMe & $52.3, \mathrm{q}$ & $3.65 \mathrm{~s}$ & $52.3, \mathrm{q}$ & $3.69 \mathrm{~s}$ \\
\hline 3 -acyl-1' & $176.0, \mathrm{~s}$ & & 172.7, s & \\
\hline $2^{\prime}$ & $34.9, \mathrm{~d}$ & $2.81 \mathrm{~m}$ & $43.4, \mathrm{t}$ & $2.35 \mathrm{~m}$ \\
\hline $3^{\prime}$ & $19.6, \mathrm{q}$ & $1.26 \mathrm{~d}(7.1)$ & $26.0, \mathrm{~d}$ & $2.19 \mathrm{dt}(13.7,6.8)$ \\
\hline $4^{\prime}$ & $19.2, \mathrm{q}$ & $1.23 \mathrm{~d}(7.1)$ & $22.82, \mathrm{q}$ & $0.95 \mathrm{~d}(6.7)$ \\
\hline $5^{\prime}$ & & & $22.85, \mathrm{q}$ & $0.92 \mathrm{~d}(6.7)$ \\
\hline
\end{tabular}

${ }^{\mathrm{a}}$ Recorded at $150 \mathrm{MHz}$ in pyridine- $d_{5} ;{ }^{\mathrm{b}}$ Recorded at $600 \mathrm{MHz}$ in pyridine- $d_{5}$.

The relative configuration of $\mathbf{1}$ was established by ROESY correlation analysis (Figure 2a). The ROESY correlations of $\mathrm{H}-9 / \mathrm{H}_{3}-19$ and $\mathrm{H}-9 / \mathrm{H}_{3}-18$ indicated that $\mathrm{H}-9$ was $\alpha$-oriented, while those of $\mathrm{H}-5 / \mathrm{H}-11 \beta, \mathrm{H}-5 / \mathrm{H}_{3}-28$, and $\mathrm{H}-17 / \mathrm{H}-11 \beta$ showed $\mathrm{H}-5$ and $\mathrm{H}-17$ were $\beta$-oriented. The ROESY correlation of $\mathrm{H}_{3}-29 / \mathrm{H}-3$ suggested that $\mathrm{H}-3$ was $\alpha$-oriented. The close coupling constant of $\mathrm{H}-3$ in 1 $(J=9.3 \mathrm{~Hz})$ and $2^{\prime} R$-cipadesin $\mathrm{A}(J=9.5 \mathrm{~Hz})[13]$, whose structure has been confirmed by X-ray crystal analysis [14], indicated that both compounds shared the same stereochemistry for H-2 and H-3 
and $\mathrm{H}-2$ was assigned to be $\alpha$-oriented. The 8,30-epoxy was then determined to be $\alpha$-oriented on the basis of the small coupling constant of H-30 $(J=2.0 \mathrm{~Hz})$ [13]. Therefore, the relative stereochemistry of 1 was established as shown in Figure 1 and it was named 14,15-didehydroruageanin A.

Figure 2. ${ }^{1} \mathrm{H}-{ }^{1} \mathrm{H}$ COSY (bold) and selected HMBC correlations of 1 (a); Selected key ROESY correlations of $\mathbf{1}(\mathbf{b})$.

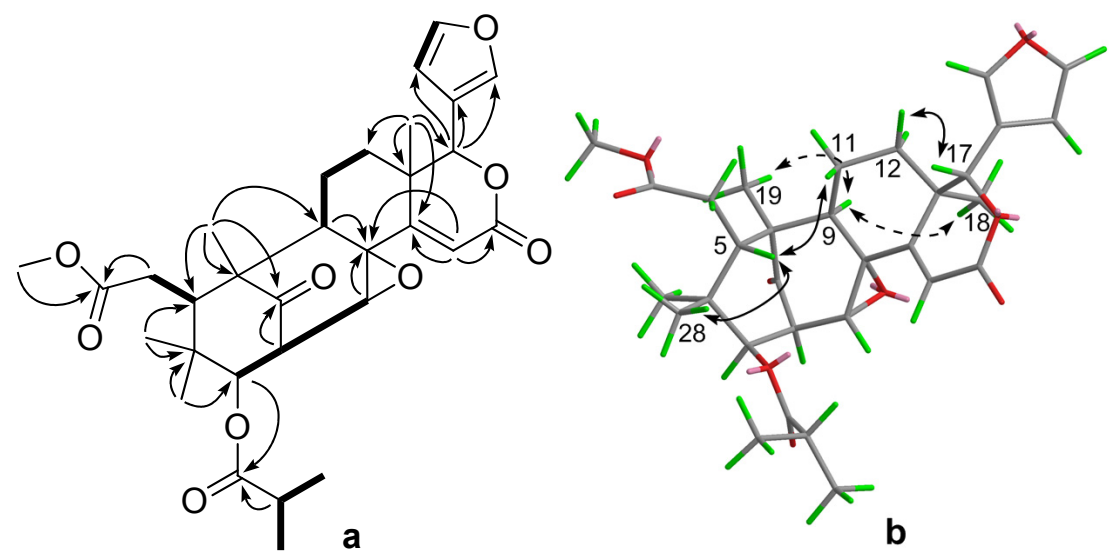

Compound 2, was obtained as a white amorphous powder. Its molecular formula $\mathrm{C}_{32} \mathrm{H}_{40} \mathrm{O}_{8}$ was established by the HREIMS ion peak at $\mathrm{m} / z 552.2715$ (calcd. 552.2723). Analysis of its ${ }^{1} \mathrm{H}-$ and ${ }^{13} \mathrm{C}-\mathrm{NMR}$ data (Table 1) showed that 2 was also a mexicanolide-type compound, very similar to the known compound seneganolide A [15]. The only differences in the NMR data of the two compounds was the upfield-shift of the signals for C-3 ( $\delta_{\mathrm{C}}$ from 80.2 to 79.1$)$ and the appearance of additional signals for a 3-methylbutyryl group $\left[\delta_{\mathrm{H}} 0.92(3 \mathrm{H}, \mathrm{d}, J=6.7 \mathrm{~Hz}), 0.95(3 \mathrm{H}, \mathrm{d}, J=6.7 \mathrm{~Hz}), 2.19(1 \mathrm{H}\right.$, dt, $J=13.7,6.8 \mathrm{~Hz}), 2.35(2 \mathrm{H}, \mathrm{m}) ; \delta_{\mathrm{C}} 22.82 \mathrm{CH}_{3}, 22.85 \mathrm{CH}_{3}, 26.0 \mathrm{CH}, 43.4 \mathrm{CH}_{2}, 172.7 \mathrm{C}$, which suggested that compound 2 was the 3-O-methylbutyryl derivative of seneganolide A. ${ }^{1} \mathrm{H}-{ }^{1} \mathrm{H}$ COSY correlations $\mathrm{H}-4^{\prime} / \mathrm{H}-3^{\prime} / \mathrm{H}-2^{\prime}$ and the HMBC correlation $\mathrm{H}-3 / \mathrm{C}-1^{\prime}$ (Figure 3a) further confirmed this conclusion. ROESY correlation analysis (Figure 3b) also supported that both compounds shared the same stereochemistry. Thus, the relative structure of $\mathbf{2}$ was elucidated as shown in Figure 1 and it was named 3-O-methylbutyrylseneganolide A.

Figure 3. ${ }^{1} \mathrm{H}-{ }^{1} \mathrm{H}$ COSY (bold) and selected HMBC correlations of 2 (a); Selected key ROESY correlations of 2 (b).

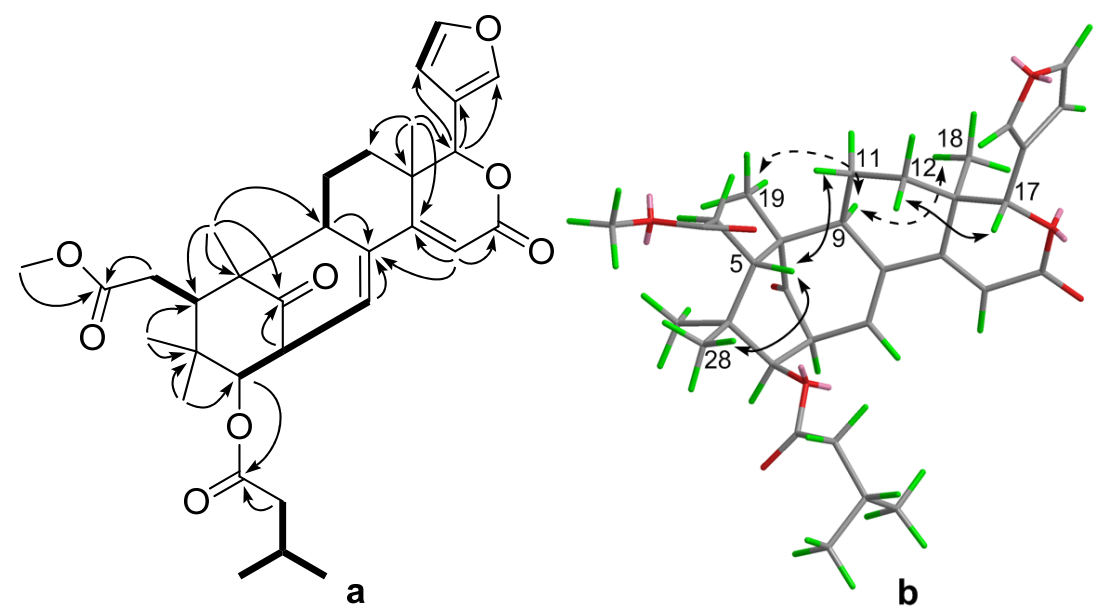


Six known limonoids were also isolated and identified by spectroscopic methods to be seneganolide A (3) [15], 1,3-dideacetylkhivorin (4) [16], 7-deacetylkhivorin (5) [7], 3-deacetylkhivorin (6) [11], 1-deacetylkhivorin (7) [17], and 3-deacetyl-7-oxokhivorin (8) [18]. Among these known limonoids, compounds $3,4,7$, and $\mathbf{8}$ were obtained from $K$. ivorensis for the first time.

Limonoids 1-8 were all evaluated for their cytotoxic activities against five human tumor cell lines: myeloid leukemia (HL-60), hepatocellular carcinoma (SMMC-7721), lung cancer (A-549), breast cancer (MCF-7), and colon cancer (SW480). However, only compounds 2, 3, and 4 exhibited cytotoxicity against certain tumor cell lines with the $\mathrm{IC}_{50}$ values in the range of 21.1-39.5 $\mu \mathrm{M}$ (Table 2).

Table 2. The cytotoxicity $\left(\mathrm{IC}_{50} \mu \mathrm{M}\right)$ of isolated compounds $\mathbf{1 - 8}$.

\begin{tabular}{cccccc}
\hline Compound & HL-60 & SMMC-7721 & A-549 & MCF-7 & SW480 \\
\hline $\mathbf{1}$ & $>40$ & $>40$ & $>40$ & $>40$ & $>40$ \\
$\mathbf{2}$ & $>40$ & $>40$ & 37.3 & $>40$ & $>40$ \\
$\mathbf{3}$ & 21.2 & 21.1 & 23.8 & $>40$ & 32.6 \\
$\mathbf{4}$ & $>40$ & $>40$ & 39.5 & 26.1 & $>40$ \\
$\mathbf{5}$ & $>40$ & $>40$ & $>40$ & $>40$ & $>40$ \\
$\mathbf{6}$ & $>40$ & $>40$ & $>40$ & $>40$ & $>40$ \\
$\mathbf{7}$ & $>40$ & $>40$ & $>40$ & $>40$ & $>40$ \\
$\mathbf{8}$ & $>40$ & $>40$ & $>40$ & $>40$ & $>40$ \\
Cisplatin $^{\text {a }}$ & 1.1 & 4.5 & 6.6 & 13.1 & 11.1 \\
\hline \multicolumn{5}{c}{${ }^{a}$ Positive control. }
\end{tabular}

\section{Experimental}

\subsection{General Information}

Optical rotations were obtained with a JASCO P-1020 polarimeter. UV spectra were measured with a Shimadzu UV 2401PC. IR spectra (KBr) were determined on a Bruker Tensor-27 infrared spectrophotometer. 1D- and 2D-NMR spectra were recorded on Bruker AM-400, Bruker DRX-500 and Avance III 600 spectrometers with TMS as an internal standard (Karlsruhe, Germany). ESIMS and HREIMS recorded on a Xevo TQ-S mass spectrometer (Manchester, UK) and a Waters AutoSpec Premier P776 instrument (Milford, CT, USA), respectively. Semi-preparative HPLC was carried out using a Waters system (Milford, CT, USA) consisting of a 600 pump and a 2996 Photodiode Array Detector. Silica gel (200-300 mesh, Qingdao Marine Chemical Factory, Qingdao, China), Sephadex LH-20 gel (40-70 $\mu \mathrm{M}$, Amersham Pharmacia Biotech AB, Uppsala, Sweden), and MCI gel (CHP20/P120, 75-150 $\mu \mathrm{M}$, high porous polymer, Mitsubishi Chemical Corporation, Japan) were used for column chromatography (CC).

\subsection{Plant Material}

The fruits of K. ivorensis were collected from Xishuangbanna Tropical Botanical Garden (XTBG), Chinese Academy of Science (CAS), Mengla Country, Yunnan Province, People's Republic of China, in July 2013 and were identified by one of the authors (Y.-K. Xu). A voucher specimen (No. 028765) was deposited in the herbarium of XTBG. 


\subsection{Extraction and Isolation}

The air-dried and powdered fruits of K. ivoremsis $(4.0 \mathrm{~kg})$ were extracted three times (each for 7 days) with $\mathrm{EtOH}-\mathrm{H}_{2} \mathrm{O}(95 / 5, v / v, 30 \mathrm{~L})$ at room temperature. Removal of solvent from the combined extracts under vacuum afforded a crude residue (200 g). The residue was then suspended in $\mathrm{H}_{2} \mathrm{O}$ and partitioned with EtOAc (60 g). The EtOAc-soluble fraction was subjected to silica gel CC (petroleum ether-acetone from $1 / 0$ to $0 / 1, v / v)$ to produce four fractions $(1-4)$. Fraction $1(5.0 \mathrm{~g})$ was subjected to MCI gel CC $\left(\mathrm{MeOH}-\mathrm{H}_{2} \mathrm{O}\right.$ from $1 / 6$ to $\left.1 / 1, v / v\right)$ to give $4(12 \mathrm{mg}), 5(5 \mathrm{mg})$, and $6(7 \mathrm{mg})$. Fraction $2(12.5 \mathrm{~g})$ was subjected to silica gel CC to obtain $3(600 \mathrm{mg})$ and sub-fraction $2 \mathrm{~A}(10 \mathrm{mg})$. Fraction $2 \mathrm{~A}$ was then purified by semi-preparative HPLC ( $\mathrm{MeOH}-\mathrm{H}_{2} \mathrm{O}$ from $2 / 3$ to $\left.7 / 3, v / v\right)$ to yield $2(4 \mathrm{mg})$. Fraction $3(2.0 \mathrm{~g})$ was separated by Sephadex LH-20 CC eluted with $\mathrm{MeOH}-\mathrm{H}_{2} \mathrm{O}$ (from $1 / 4$ to $1 / 1, v / v$ ) and further purified by semi-preparative HPLC to give 1 (3 mg). Fraction $4(12.0 \mathrm{~g})$ was applied to a silica gel column and eluted with petroleum ether-acetone (from $1 / 9$ to $1 / 1, v / v)$ to give $7(800 \mathrm{mg}$ ) and a sub-fraction 4A (50 mg), purification of which by Sephadex LH-20 CC (MeOH- $\mathrm{H}_{2} \mathrm{O}$ from 3/7 to 3/2, $v / v)$ and semi-preparative $\mathrm{HPLC}\left(\mathrm{CH}_{3} \mathrm{CN}-\mathrm{H}_{2} \mathrm{O}\right.$ from $2 / 3$ to $\left.7 / 3, v / v\right)$ yielded $8(4 \mathrm{mg})$.

\subsection{Spectral Data}

14,15-Didehydroruageanin A (1). White amorphous powder; $[\alpha]^{20.5}+9.3(c \quad 0.045, \mathrm{MeOH})$; UV $(\mathrm{MeOH}) \lambda_{\max } \mathrm{nm}(\log \varepsilon) 204.8$ (4.23); IR (KBr) $v_{\max }\left(\mathrm{cm}^{-1}\right): 2972,2931,1732,1634,1460,1384,1271$, 1197, 1114, 1028; ${ }^{1} \mathrm{H}$ - and ${ }^{13} \mathrm{C}-\mathrm{NMR}$ data, see Table 1; positive ESIMS $\mathrm{m} / \mathrm{z} 555[\mathrm{M}+\mathrm{H}]{ }^{+}$; HREIMS $\mathrm{m} / \mathrm{z}$ 554.2501 M (calcd for $\mathrm{C}_{31} \mathrm{H}_{38} \mathrm{O}_{9}, 554.2516$ ).

3-O-Methylbutyrylseneganolide A (2). White amorphous powder; $[\alpha]^{15.4}+51.0(c 0.076, \mathrm{MeOH})$; UV $(\mathrm{MeOH}) \lambda_{\max } \mathrm{nm}(\log \varepsilon) 203$ (4.08), 282.4 (3.89); IR (KBr) $v_{\max }\left(\mathrm{cm}^{-1}\right): 2961,1630,1463,1384,1295$, 1256, 1167, 1119, 1107, 1028, 1001; ${ }^{1} \mathrm{H}$ - and ${ }^{13} \mathrm{C}-\mathrm{NMR}$ data, see Table 1; positive ESIMS $\mathrm{m} / z 553$ $[\mathrm{M}+\mathrm{H}]^{+}$; HREIMS $m / z$ 552.2715 M (calcd for $\mathrm{C}_{32} \mathrm{H}_{40} \mathrm{O}_{8}, 552.2723$ ).

\subsection{Cytotoxicity Assay}

The MTT method [19] was used for assessing the cytotoxicity of all isolated compounds against the five tumor cell lines (HL-60 human myeloid leukemia, SMMC-7721 hepatocellular carcinoma, A-549 lung cancer, MCF-7 breast cancer, and SW480 colon cancer) with cisplatin as the positive control.

\section{Conclusions}

In summary, three mexicanolide-type limonoids, 14,15-didehydroruageanin A (1), 3-O-methylbutyrylseneganolide A (2), and seneganolide A (3), along with five known D-seco limonoids, 1,3-dideacetylkhivorin (4), 7-deacetylkhivorin (5), 3-deacetylkhivorin (6), 1-deacetylkhivorin (7) and 3-deacetyl-7-oxokhivorin (8), were isolated from the fruits of Khaya ivorensis. Among these compounds, 1 and 2 were new compounds; and compounds 3, 4, 7, and $\mathbf{8}$ were obtained from this plant for the first time. The cytotoxicity evaluation showed that only compounds $\mathbf{2}, \mathbf{3}$, and $\mathbf{4}$ exhibited cytotoxicity against certain tumor cell lines. 


\section{Supplementary Materials}

Supplementary materials can be accessed at: http://www.mdpi.com/1420-3049/19/3/3004/s1.

\section{Acknowledgments}

NSFC-U1302222, CAS 135 program (XTBG-F02), and Ethnobotanical Investigation of Plants for Industrialization in Southwest China (2012FY110300) are gratefully acknowledged.

\section{Author Contributions}

YKX, PZ, and KLJ designed research; KLJ, SGL, ZN, HBH, and XLZ performed research and analyzed the data; KLJ, SGL, and YKX wrote the paper. All authors read and approved the final manuscript.

\section{Conflicts of Interest}

The authors declare no conflict of interest.

\section{References}

1. Fang, X.; Di, Y.T.; Hao, X.J. The advances in the limonoid chemistry of the Meliaceae family. Curr. Org. Chem. 2011, 15, 1363-1391.

2. Tan, Q.G.; Luo, X.D. Meliaceous limonoids: Chemistry and biological activities. Chem. Rev. 2011, 111, 7437-7522.

3. Chen, S.K.; Li, H.; Chen, B.Y. In Zhongguo Zhiwu Zhi; Science Press: Beijing, China, 1997; pp. 46-47.

4. Zhang, B.; Wang, Y.; Yang, S.P.; Zhou, Y.; Wu, W.B.; Tang, W.; Zuo, J.P.; Li, Y.; Yue, J.M. Ivorenolide A, an unprecedented immunosuppressive macrolide from Khaya ivorensis: Structural elucidation and bioinspired total synthesis. J. Am. Chem. Soc. 2012, 134, 20605-20608.

5. Agbedahunsi, J.; Fakoya, F.; Adesanya, S. Studies on the anti-inflammatory and toxic effects of the stem bark of Khaya ivorensis (Meliaceae) on rats. Phytomedicine 2004, 11, 504-508.

6. Zhang, B.; Yang, S.P.; Yin, S.; Zhang, C.R.; Wu, Y.; Yue, J.M. Limonoids from Khaya ivorensis. Phytochemistry 2009, 70, 1305-1308.

7. Adesogan, E.K.; Taylor, D.A.H. Limonoid extractives from Khaya ivorensis. J. Chem. Soc. C 1970, 12, 1710-1714.

8. Adesida, G.; Adesogan, E.; Okorie, D.; Taylor, D.; Styles, B. The limonoid chemistry of the genus Khaya (Meliaceae). Phytochemistry 1971, 10, 1845-1853.

9. Taylor, D.A.H. The structure of an extractive from Khaya ivorensis. Phytochemistry 1977, 16, 1847-1849.

10. Vanucci, C.; Lange, C.; Lhommet, G.; Dupont, B.; Davoust, D.; Vauchot, B.; Clement, J.L.; Brunck, F. An insect antifeedant limonoid from seed of khaya ivorensis. Phytochemistry 1992, 31, 3003-3004. 
11. Abdelgaleil, S.A.M.; Hashinaga, F.; Nakatani, M. Antifungal activity of limonoids from Khaya ivorensis. Pest Manag. Sci. 2005, 61, 186-190.

12. Li, M.Y.; Yang, X.B.; Pan, J.Y.; Feng, G.; Xiao, Q.; Sinkkonen, J.; Satyanandamurty, T.; Wu, J. Granatumins A-G, limonoids from the seeds of a Krishna Mangrove, Xylocarpus granatum. J. Nat. Prod. 2009, 72, 2110-2114.

13. Gan, L.S.; Wang, X.N.; Wu, Y.; Yue, J.M. Tetranortriterpenoids from Cipadessa baccifera. J. Nat. Prod. 2007, 70, 1344-1347.

14. Siva, B.; Poornima, B.; Venkanna, A.; Prasad, K.R.; Sridhar, B.; Nayak, V.L.; Ramakrishna, S.; Babu, K.S. Methyl angolensate and mexicanolide-type limonoids from the seeds of Cipadessa baccifera. Phytochemistry 2014, 98, 174-182.

15. Abdelgaleil, S.A.M.; Iwagawa, T.; Doe, M.; Nakatani, M. Antifungal limonoids from the fruits of Khaya senegalensis. Fitoterapia 2004, 75, 566-572.

16. Akisanya, A.; Arene, E.; Bevan, C.; Ekong, D.; Nwaji, M.; Okogun, J.; Powell, J.; Taylor, D. West African timbers. Part XII. The inter-relation of gedunin and khivorin. J. Chem. Soc. C 1966, 506-509.

17. Bickii, J.; Njifutie, N.; Foyere, J.A.; Basco, L.K.; Ringwald, P. In vitro antimalarial activity of limonoids from Khaya grandifoliola C.D.C. (Meliaceae). J. Ethnopharmacol. 2000, 69, 27-33.

18. Tchimene, M.K.; Ngamga, D.; Tane, P.; Sterner, O.; Connolly, J.D. 3,7-Dideacetyl-6 alpha-hydroxykhivorin, a new limonoid from Khaya senegalensis (Meliaceae). Bull. Chem. Soc. Ethiop. 2006, 20, 69-73.

19. Mosmann, T. Rapid colorimetric assay for cellular growth and survival: Application to proliferation and cytotoxicity assays. J. Immunol. Methods 1983, 65, 55-53.

Sample Availability: Samples of the compounds 1-8 are available from the authors.

(C) 2014 by the authors; licensee MDPI, Basel, Switzerland. This article is an open access article distributed under the terms and conditions of the Creative Commons Attribution license (http://creativecommons.org/licenses/by/3.0/). 